\title{
Identification of new genes associated with intermediate resistance of Enterococcus faecalis to divercin V41, a pediocin-like bacteriocin
}

\begin{abstract}
Correspondence
Djamel Drider

drider@enitiaa-nantes.fr
\end{abstract}

Received 1 December 2006

Revised 15 January 2007

Accepted 19 January 2007

\author{
Ségolène Calvez, ${ }^{1}$ Alain Rincé, ${ }^{2}$ Yanick Auffray, ${ }^{2}$ Hervé Prévost ${ }^{1}$ \\ and Djamel Drider ${ }^{1}$
${ }^{1}$ UMR-INRA 1014 SECALIM, ENITIAA, Rue de la Géraudière, BP 82225, Nantes Cedex 3, France \\ '2Laboratoire de Microbiologie de l'Environnement, EA 956, USC INRA 2017, IRBA, Université \\ de Caen, Caen Cedex, France
}

\begin{abstract}
It has been suggested that resistance to class lla bacteriocins occurs at either a low or a high level. In listerial strains, low-level resistance (2-4-fold) to class lla bacteriocins is attributed to alterations in membrane lipid composition. In Listeria monocytogenes and Enterococcus faecalis, high-level resistance (1000-fold) correlates with inactivation of the $m p t A C D$ operon, which encodes the $\mathrm{Ell}_{\mathrm{t}}^{\mathrm{Man}}$ mannose permease of the phosphotransferase system (PTS). Previous studies reported that in L. monocytogenes, high-level resistance involved the $\sigma^{54}$ factor and the ManR activator. In this investigation, three genes associated with the resistance of Ent. faecalis JH2-2 to divercin V41, a pediocin-like bacteriocin from Carnobacterium divergens V41, were clearly identified by screening an insertional mutant library of Ent. faecalis $\mathrm{JH} 2-2$. These genes correspond to the well-known rpoN gene, which encodes $\sigma^{54}$ factor, and to genes encoding a glycerophosphoryl diester phosphodiesterase (GlpQ) and a protein with a putative phosphodiesterase function (PDE). Resistance of the three mutants defective in the aforementioned genes appeared to be graduated: the $r p o N$ mutant was more resistant than the $g / p Q$ mutant, which was more resistant than the $p d e$ mutant. Moreover, this resistance was specific to class lla bacteriocins.
\end{abstract}

\section{INTRODUCTION}

The past few years have seen the emergence of class IIa bacteriocins produced by lactic acid bacteria as one of the most interesting groups of antimicrobial peptides for food preservation (Cleveland et al., 2001) and in medicine as antiviral agents (Wachsman et al., 1999, 2003). Class IIa bacteriocins, referred to as pediocin-like bacteriocins, are listericidal, small ( $<10 \mathrm{kDa})$, heat stable, non-lanthioninecontaining peptides of 37 to 48 amino acids with a consensus sequence $\mathrm{YGNGVXCX}_{4}(\mathrm{C}) \mathrm{XVX}_{4} \mathrm{~A}$ (X denotes any amino acid) in their charged $\mathrm{N}$-terminal region (Drider et al., 2006). These bacteriocins also have a similar tertiary structure (Frégeau-Gallagher et al., 1997; Uteng et al., 2003) and mode of action (Ennahar et al., 2000). A promising method of food protection by using class IIa bacteriocins could be compromised by the development of resistant strains. This drawback could be overcome by using combinations of bacteriocins (Bouttefroy \& Millière,

\footnotetext{
Abbreviations: ADT, agar diffusion test; $A U$, arbitrary units; DvnV41, divercin V41; DvnRV41, recombinant divercin V41; MesY105, mesentericin Y105; Ped PA-1/AcH, pediocin PA-1/AcH; PDE, phosphodiesterase; PTS, phosphotransfersase system; RAPD, random amplified polymorphic DNA.
}

2000), or bacteriocins combined with other sublethal treatments such as sodium diacetate and sodium lactate (Uhart et al., 2004). These combinations appear to be more efficient in controlling the growth of the foodborne pathogen Listeria monocytogenes. Resistance to class IIa bacteriocins has been studied but remains poorly understood overall. Studies aimed at characterizing the resistance mechanisms of bacterial targets have revealed the stability of this phenomenon (Rekhif et al., 1994; Dykes \& Hastings, 1998), which occurs at either a low or a high level. In $L$. monocytogenes and Enterococcus faecalis, low-level resistance is attributed to alterations in membrane lipid composition (Vadyvaloo et al., 2002, 2004; Naghmouchi et al., 2006) and high-level resistance results from the inactivation of the mptACD operon, which encodes the $\mathrm{EII}_{\mathrm{t}}^{\mathrm{Man}}$ mannose permease of the phosphotransferase system (PTS) (Dalet et al., 2001; Héchard et al., 2001). The aim of this study was to gain more insights into the molecular resistance mechanism developed by Ent. faecalis $\mathrm{JH} 2-2$ in response to pediocin-like bacteriocins. In the food quality area, Ent. faecalis is used as an indicator of faecal contamination and has been shown to be implicated in outbreaks of foodborne illness, while in the clinical area this bacterium has become a serious nosocomially transmitted pathogen. Our data 
strongly suggest that inactivation of genes encoding a glycerophosphoryl diester phosphodiesterase (GlpQ) and a protein with a putative phosphodiesterase function (PDE) confer a resistant character to Ent. faecalis $\mathrm{JH} 2-2$ towards divercin V41.

\section{METHODS}

Bacterial strains and growth conditions. Ent. faecalis $\mathrm{JH} 2-2$ (Yagi \& Clewell, 1980) and its mutant derivatives were grown without shaking in M17 medium (Biokar) supplemented with glucose at $0.5 \%(\mathrm{w} / \mathrm{v})$ (Terzaghi \& Sandine, 1975). When necessary, erythromycin $\left(150 \mu \mathrm{g} \mathrm{ml}^{-1}\right)$ or tetracycline $\left(15 \mu \mathrm{g} \mathrm{ml}^{-1}\right)$ was added to the growth medium. Carnobacterium divergens V41 (Pilet et al., 1995), Leuconostoc mesenteroides Y105 (Héchard et al., 1992) and Pediococcus acidilactici B5627 (University of Poitiers, France) were grown in MRS (de Man-Rogosa-Sharpe) medium (Biokar). Escherichia coli Origami, harbouring plasmid pCR03, which confers the ability to synthesize recombinant divercin V41 (Richard et al., 2004), was grown at $37^{\circ} \mathrm{C}$ with shaking in LB medium containing ampicillin $\left(100 \mu \mathrm{g} \mathrm{ml}^{-1}\right)$ and chloramphenicol $\left(30 \mu \mathrm{g} \mathrm{ml}^{-1}\right)$ (Richard et al., 2004). Listeria innocua F (ENITIAA) was grown in Elliker medium (Biokar) at $30^{\circ} \mathrm{C}$, without shaking.

Production of pediocin-like bacteriocins. Divercin V41 (DvnV41), mesentericin Y105 (MesY105) and pediocin PA-1/AcH (Ped PA-1/AcH) were prepared from C. divergens V41, Leuconostoc mesenteroides Y105 and P. acidilactici B5627, respectively. Samples $(1 \mathrm{ml})$ of cell cultures of each strain were centrifuged $(6 \mathrm{~min}$, $5000 \mathrm{~g}, 4^{\circ} \mathrm{C}$ ), then the recovered supernatant was heated for $10 \mathrm{~min}$ at $100{ }^{\circ} \mathrm{C}$ and kept at $-20^{\circ} \mathrm{C}$ until use. Recombinant divercin V41 (DvnRV41) was obtained from the heterologous host $E$. coli Origami/pCR03 and purified as described previously (Richard et al., 2004). Recombinant divercin V41 differs from natural divercin V41 by one amino acid in the N-terminal sequence, P-dvnV41 (Richard et al., 2004). DvnV41 supernatant was used for established screening conditions and for screening the mutant library, then purified DvnRV41 was used for determining the MIC.

The anti-Listeria activity of DvnV41, DvnRV41, MesY105 and Ped PA$1 / \mathrm{AcH}$ against $L$. innocua $\mathrm{F}$ was verified as previously described (Pilet et al., 1995). Briefly, $10 \mu \mathrm{l}$ samples of a twofold serial dilution in Elliker broth for each bacteriocin studied were spotted on an Elliker agar $(1 \%)$ plate inoculated with the indicator strain, L. innocua $\mathrm{F}$, at $10^{7}$ c.f.u. $\mathrm{ml}^{-1}$. Plates were incubated at $30^{\circ} \mathrm{C}$ for $16 \mathrm{~h}$. The bacteriocin activity was expressed in arbitrary units per $\mathrm{ml}\left(\mathrm{AU} \mathrm{ml}^{-1}\right)$ and was defined as the reciprocal of the lowest dilution that did not show growth inhibition of L. innocua F. Bacteriocin activity was found to be $820000 \mathrm{AU} \mathrm{ml}^{-1}$ for DvnV41, $3300000 \mathrm{AU} \mathrm{ml}^{-1}$ for DvnRV41, and $256000 \mathrm{AU} \mathrm{ml}^{-1}$ for MesY105 and Ped PA-1/AcH.

Isolation of Ent. faecalis JH2-2 divercin V41-resistant mutants. The library of insertional mutants of Ent. faecalis JH2-2 used in this study was constructed by Le Breton et al. (2002) as follows. DNA fragments of $200 \mathrm{bp}$ to $1.5 \mathrm{~kb}$ were generated by partial digestion of chromosomal DNA from Ent. faecalis JH2-2 with AluI then cloned into pORI19 (pWV01-derived Ori ${ }^{+} \mathrm{RepA}^{-}$) using the $\mathrm{RepA}^{+}$helper E. coli strain EC101 (Law et al., 1995) to obtain a bank of approximately 37200 recombinant plasmids. A mixture of these recombinant plasmids was then transferred into Ent. faecalis $\mathrm{JH} 2-2$ that had previously received the pWV01-derived $\mathrm{Ori}^{+}$ $\mathrm{RepA}^{\mathrm{TS}} \mathrm{pG}^{+}$host3 plasmid (pVE6007) (Maguin et al., 1992). Clones were grown at $30{ }^{\circ} \mathrm{C}$ in GM17 medium containing erythromycin and chloramphenicol (the thermosensitive $\operatorname{RepA}^{\mathrm{TS}}$ protein is active at $30{ }^{\circ} \mathrm{C}$ and allowed replication of $\mathrm{pG}^{+}$host 3 and pORI19 recombinant plasmids). Cells were transferred into GM17 containing erythromycin $\left(150 \mu \mathrm{g} \mathrm{ml}^{-1}\right)$ and the incubation temperature was shifted to $42{ }^{\circ} \mathrm{C}$ to inactivate the RepA ${ }^{\mathrm{TS}}$ protein and consequently to provoke the loss of $\mathrm{pG}^{+}$host 3 and the integration of the pORI19 recombinant plasmid by homologous recombination. Mutants (9600) were then screened for resistance to DvnV41 as follows: individual clones were grown at $37^{\circ} \mathrm{C}$ in 96 -well microtitre plates containing GM17 broth with $150 \mu \mathrm{g}$ erythromycin $\mathrm{ml}^{-1}$ then replica plated in GM17 broth containing $5 \%(\mathrm{v} / \mathrm{v})$ DvnV41 $\left(820000 \mathrm{AU} \mathrm{ml}^{-1}\right)$. Integrated plasmids from all selected DvnV41resistant mutants were excised as previously described by Le Breton et al. (2002) and used to identify the insertion loci. After sequencing the DNA insert carried by the pORI19 recombinant plasmid from each mutant, the nucleotide sequence was compared to that of the Ent. faecalis (V583) genomic sequence available at The Institute for Genomic Research (http://www.tigr.org/).

Analysis of mRNAs by RT-PCR. Total RNA of Ent. faecalis JH2-2 was isolated from exponentially growing cells in GM17 broth using the RNeasy Midi kit (Qiagen). For reverse transcriptions $10 \mu \mathrm{g}$ of the RNA preparation was treated for $30 \mathrm{~min}$ at $37^{\circ} \mathrm{C}$ with $20 \mathrm{U}$ RNasefree DNase I (Roche Molecular Biochemicals) followed by a phenolacid extraction at $65^{\circ} \mathrm{C}$. Reverse transcriptase reactions were performed on $2 \mu \mathrm{g}$ of the RNA at $37^{\circ} \mathrm{C}$ using the Omniscript RT kit (Qiagen) with 20 pmol random hexamer primers. cDNA was then purified using the QIAquick kit (Qiagen) and PCRs were performed with purified cDNA as template and 20 pmol primers listed in Table 1 using $2.5 \mathrm{U}$ Taq DNA polymerase (Q-BIOgene). Amplifications were carried out for 30 cycles consisting of $94^{\circ} \mathrm{C}$ for $30 \mathrm{~s}, 56^{\circ} \mathrm{C}$ for $30 \mathrm{~s}$, and $72^{\circ} \mathrm{C}$ for $1 \mathrm{~min}$, then the samples were analysed on a $1 \%$ agarose gel in TAE ( $40 \mathrm{mM}$ Tris-acetate $\mathrm{pH} 8.0,1 \mathrm{mM}$ EDTA) buffer. The absence of contaminating genomic DNA was checked by regular PCR performed under the same conditions, except that the reverse transcriptase was replaced by $\mathrm{H}_{2} \mathrm{O}$. A positive control was also performed by replacing cDNA with genomic DNA (data not shown).

Complementation test. The EF0011 (pde gene) and EF2163 ( $g l p Q$ gene) were amplified by PCR from chromosomal DNA of Ent. faecalis $\mathrm{JH} 2-2$ using specifically designed pairs of primers. The pde gene was amplified by primers $p d e \mathrm{~F} 5^{\prime}$-GACAATTTCGTCGACCAAAGAGC-3' and $p d e \mathrm{R}$ 5'-CTTTGGATCCCTTCACTCCTGTTC-3', containing SalI and BamHI restriction sites (underlined) respectively; the $g l p Q$ gene was amplified with primers $g l p Q F 5$ '-GTTGGATCCTAAAAAGAAGCCC-3' and $g l p Q R \quad 5^{\prime}$-CCTACGATATCTAATACTTTCTCC-3', containing BamHI and EcoRV restriction sites (underlined) respectively. Each PCR product was digested with appropriate restriction enzymes and cloned into pAM401 vector (Wirth et al., 1986), itself cut with the same restriction enzymes. The recombinant plasmids were directly transferred into the Ent. faecalis mutant strain by electroporation using the following conditions: $25 \mu \mathrm{F}, 400 \Omega$ and $2500 \mathrm{~V}$ in a $0.2 \mathrm{~cm}$ cuvette (Pulse Controller Plus; Bio-Rad). The resulting cells were plated onto GM17 plates containing chloramphenicol $\left(10 \mu \mathrm{g} \mathrm{ml}^{-1}\right)$ and erythromycin $\left(10 \mu \mathrm{g} \mathrm{ml}^{-1}\right)$. Plates were incubated at $37^{\circ} \mathrm{C}$ for $48 \mathrm{~h}$. As a negative control, we used cells harbouring only plasmid pAM401.

Susceptibility/resistance test to divercin V41. Susceptibilities of Ent. faecalis JH2-2 wild-type, mutant strains 35A1 (pde), 36H4 $(g l p x Q)$ and transformants $35 \mathrm{~A} 1+p d e, 36 \mathrm{H} 4+g l p Q$ toward DvnV41 were tested. Cultures were diluted (1/100) and plated onto GM17 medium containing $1 \%$ agar; $10 \mu \mathrm{l}$ samples of DvnV41 were spotted and the plates were incubated at $37^{\circ} \mathrm{C}$ for $16 \mathrm{~h}$. Inhibition haloes were observed and compared between the different strains.

Identification of Ent. faecalis JH2-2 divercin V41-resistant mutants. Identification of the mutants was performed by phenotypic and molecular methods. After Gram staining, each mutant strain was checked for its catalase and oxidase activities. Identification was completed by PCR-RAPD (random amplified 
Table 1. Primers used in RT-PCR experiments

Locations of these primers are indicated in Fig. 1.

\begin{tabular}{|c|c|c|c|}
\hline Primer set & Sequence $\left(5^{\prime}-3^{\prime}\right)$ & $\begin{array}{c}\text { Size of } \\
\text { amplimer }(\mathbf{b p})\end{array}$ & Amplified gene \\
\hline EF2163F & CACATCGAGGAAGTAAAGGC & 508 & $g l p Q$ \\
\hline EF2163R & CCCGCTTGACTTAAATCCTC & & \\
\hline EF2162F & ACTCCATGCAAGTTTATCGC & 617 & $\operatorname{miaA}$ \\
\hline EF2162R & TAGCCAATACCTTGAGCTGC & & \\
\hline EF2161F & GCATCAATGGAAGAACTGGC & 694 & Gene encoding putative \\
\hline EF2161R & AGCGTAACTTCCATGCCTTG & & GTP-binding protein \\
\hline EF2160F & GAGTTACGCCGTTCCATGTC & 304 & $\operatorname{gln} R$ \\
\hline EF2160R & CTGAGTAAGTCCTCCTTGCG & & \\
\hline J2163F & ATTCGCGCTTGTCGATAGTT & 420 & glpQ-miaA \\
\hline J2162R & CTGACTTCACGGCAATCAAT & & \\
\hline $\mathrm{J} 2162 \mathrm{~F}$ & GCTATAAAGAATTTTTCCCG & 436 & miaA-gene encoding \\
\hline J2161R & TCATAGGCATCTGTTAATTG & & GTP-binding protein \\
\hline J2161F & GTGAACTTCGCCGGATGACA & 420 & Gene encoding \\
\hline J2160R & ATAGTAGCGAATTTGTCGAG & & GTP-binding protein- $g \ln R$ \\
\hline EF0011F & TGTTGTGGGTCTTCTCTTAG & 504 & pde \\
\hline EF0011R & TTATCGACAGACACAATGCC & & \\
\hline EF0012F & GTGCCAACTGGTTACGCCCA & 349 & $r p I I$ \\
\hline EF0012R & GATGTAGTTTGACTGGTACG & & \\
\hline EF0013F & GCGATGGAATATGTGGAACC & 603 & $d n a B$ \\
\hline EF0013R & AGCTTTATCTGTCTTGGTGC & & \\
\hline J0011F & TCATTACCAAGCGGACGGAT & 426 & $p d e+r p I I$ \\
\hline J0012R & AAGGCTTGCATTTCTTTTGC & & \\
\hline J0012F & AGGTTACACTAACGTACCAG & 439 & $r p I I+d n a B$ \\
\hline J0013R & GCACATCTGCATCTAAGAAA & & \\
\hline EF0783F & GATTTTATGTGCGAAGGATG & 404 & Gene encoding putative \\
\hline EF0783R & GTCTGTTCCATAATAGACAC & & acetyl transferase \\
\hline EF0782F & AGAAGTTGGCCATGACTCAA & 501 & $r p o N$ \\
\hline EF0782R & TATACGCTAAATTAGGCGCG & & \\
\hline J0782F & TTCAGGCATGGAAATATCCC & 403 & $r p o N+$ gene encoding \\
\hline J0783R & GCATGACTTGGGGAAAAAGG & & putative acetyl transferase \\
\hline
\end{tabular}

polymorphic DNA) using the following conditions: $1 \mu \mathrm{l}(50 \mathrm{ng})$ chromosomal DNA, $5 \mu \mathrm{l} 10 \times$ reaction buffer (New England Biolabs), $5 \mathrm{mM} \mathrm{MgCl}_{2}$ (Sigma), $1 \mathrm{mM}$ dNTPs (New England Biolabs), $0.5 \mu \mathrm{M}$ primer M13V (5'-GTTTTCCCAGTCACGAC-3') and $0.75 \mathrm{U}$ Taq DNA polymerase (New England Biolabs). The PCR reactions were carried out on a PTC-100 thermocycler (MJ Research). The cycling programme was: $3 \mathrm{~min}$ at $94{ }^{\circ} \mathrm{C}, 5 \mathrm{~min}$ at $40^{\circ} \mathrm{C}, 5 \mathrm{~min}$ at $72^{\circ} \mathrm{C}$ for 3 cycles; $1 \mathrm{~min}$ at $94^{\circ} \mathrm{C}, 2 \mathrm{~min}$ at $60^{\circ} \mathrm{C}$, $3 \mathrm{~min}$ at $72{ }^{\circ} \mathrm{C}$ for 32 cycles. Thereafter, $5 \mu \mathrm{l}$ of each PCR product was separated on a $1.5 \%$ agarose gel run at $100 \mathrm{~V}$ for $20 \mathrm{~min}$ and visualized by UV after ethidium bromide staining. A $100 \mathrm{bp}$ ladder (New England Biolabs) was used as a reference for molecular size.

MIC determination. Twofold serial dilutions of DvnRV41 in GM17 medium were placed in microplate wells (Nunc). Each well was inoculated with $50 \mu \mathrm{l}$ of Ent. faecalis JH2-2 wild-type or mutant cultures at $10^{6}$ c.f.u. $\mathrm{ml}^{-1}$. The microplate was incubated aerobically for $18 \mathrm{~h}$ at $30^{\circ} \mathrm{C}$ then $\mathrm{OD}_{600}$ was measured hourly using an UltraMicroplate Reader (Bio-Tek Instruments). Sterile medium incubated under the same conditions was used as a blank. The MIC was calculated from the highest dilution showing complete inhibition of the tested strain $\left(\mathrm{OD}_{600}\right.$ equals $\mathrm{OD}_{600}$ of the blank). The MIC determinations were repeated independently three times and the mean value is presented in the Results.

Cross-resistance to bacteriocins and antibiotics. The resistance level of Ent. faecalis JH2-2 and mutants resistant to DvnV41 was tested against class IIa bacteriocins (DvnV41, MesY105 and Ped PA-1/AcH), the class I bacteriocin nisin (Sigma) and the following antibiotics: cephalothin $\left(0.01 \mathrm{mg} \mathrm{ml}^{-1}\right)$ (Sigma), penicillin $\mathrm{G}$ (10 IU) (Biomérieux), and streptomycin (10 IU) (Bio-Rad). Bacteriocin activity was assessed by the agar diffusion test (ADT) against L. innocua $\mathrm{F}$ as indicator strain (Pilet et al., 1995). Briefly, brain heart infusion (BHI; Biokar) agar plates were inoculated with $1 \mathrm{ml}$ of Ent. faecalis JH2-2 wild-type or mutant strains at $10^{7}$ c.f.u. $\mathrm{ml}^{-1}$. Next, $10 \mu \mathrm{l}$ samples of a supernatant culture containing any of the class IIa bacteriocins cited above or nisin at $10 \mathrm{mg} \mathrm{ml}^{-1}$ were spotted onto the agar plate and incubated at $30^{\circ} \mathrm{C}$ for $16 \mathrm{~h}$. Cephalothin, or a disk of penicillin $\mathrm{G}$ or streptomycin, was applied in a similar way and plates were incubated at $30{ }^{\circ} \mathrm{C}$ for $16 \mathrm{~h}$. After this, the plates were inspected for the formation of inhibition zones by measuring the diameter of each halo. 
Database searches and sequence analyses. Searches for promoter locations and prediction of the $p d e$ and $g l p Q$ transcription start point were performed with the neural network program (http:// www.fruitfly.org/seq_tools/promoter.html). Ent. faecalis genome analyses were performed using the Ent. faecalis (V583) genomic sequence available at The Institute for Genomic Research (http:// www.tigr.org/).

\section{RESULTS}

\section{Isolation of Ent. faecalis JH2-2 DvnV41-resistant mutants}

The 9600 insertional mutant library of Ent. faecalis JH2-2 was screened for DvnV41 $\left(820000 \mathrm{AU} \mathrm{ml}^{-1}\right)$ resistant mutants. After $9 \mathrm{~h}$ of incubation at $37^{\circ} \mathrm{C}$, growth was observed for only six clones, named 35A1, 35H1, 35H6, $36 \mathrm{H} 4,36 \mathrm{H} 7$ and $36 \mathrm{H} 9$. The sequences of DNA inserts excised from the six DvnV41-resistant clones were compared to the DNA genome sequence of Ent. faecalis V583. Results revealed that the plasmid excised from mutant $35 \mathrm{~A} 1$ contained a 385 bp DNA insert that corresponds to an internal region (nucleotides 854-1238) of a 1977 bp ORF named EF0011. The plasmid from mutant $36 \mathrm{H} 4$ contained a 431 bp DNA insert that corresponds to an internal region (nucleotides 234-664) of a 747 bp ORF (EF2163), while those of mutants $35 \mathrm{H} 1,35 \mathrm{H} 6,36 \mathrm{H} 7$ and $36 \mathrm{H} 9$ were identical and harboured a $412 \mathrm{bp}$ insert corresponding to nucleotides 49-460 of the 1314 bp EF0782 ORF.

\section{DNA sequence analysis}

The Ent. faecalis (V583) genomic sequence in the region corresponding to the insertion locus in mutant 35A1 provided evidence for the presence of a ribosome-binding site sequence (GGAGG) located $6 \mathrm{nt}$ upstream of the EF0011 ORF initiation codon (ATG). Translation of this ORF should allow synthesis of a 658 amino acid protein sharing homology with a putative phosphoesterase of the desert hedgehog $(\mathrm{DHH})$ protein family, enzymes that hydrolyse polyphosphates into $\mathrm{P}_{\mathrm{i}}$. A prediction of transmembrane topology with the TMpred program (Hofmann \& Stoffel, 1993) revealed that amino acid regions 10-28 and 34-53 could be membrane-spanning segments. In Ent. faecalis (V583), the EF0011 ORF is flanked by two genes, $r p s R$ and $r p I I$, encoding ribosomal protein $\mathrm{S} 18$ and ribosomal protein L9, respectively (Fig. 1). In this study, we refer to EF0011 ORF as the pde gene.

The EF0782 ORF (insertion locus 35H1, 35H6, 36H7 and $36 \mathrm{H} 9)$ is preceded by a ribosome-binding site sequence (GGAGG) located $8 \mathrm{nt}$ upstream of the initiation codon (ATG). This ORF, which corresponds to the rpoN gene, encodes the 443 amino acid RNA polymerase $\sigma^{54}$ factor (Dalet et al., 2000). It is preceded by a gene encoding a tRNA (tRNA-Arg2) oriented in the opposite direction and followed by the EF0783 ORF, which encodes a 625 amino acid putative acetyl transferase (Fig. 1). Immediately downstream of the last codon of the $r p o N$ gene, there is a $201 \mathrm{bp}$ intergenic region, which contains an inverted repeat $\left(5^{\prime}\right.$ AAACAACCAAAGCTTATGA $\left(\mathrm{N}_{7}\right)$ TCATAAGCTTTGGTTGTTT-3'; $\left.\Delta G=-30.2 \mathrm{kcal} \mathrm{mol}^{-1} ; \quad-126.4 \mathrm{~kJ} \mathrm{~mol}^{-1}\right)$, which could act as a rho-independent terminator (Fig. 1).

The EF2163 ORF (insertion site in mutant 36H4) encodes a 248 amino acid protein $(28.4 \mathrm{kDa})$ sharing high similarity with putative glycerophosphoryl diester phosphodiesterase enzymes, which are known to hydrolyse deacylated phospholipids into glycerol 3-phosphate and the corresponding alcohols. In this study, this ORF is named the $g l p Q$ gene. The entire amino acid sequence, deduced from the $g l p Q$ gene, was highly hydrophobic. Moreover, the $g l p Q$ gene is preceded by the EF2164 ORF, which encodes a putative membrane protein of 603 amino acids with an unknown function. Immediately downstream of the termination codon of the glpQ gene, the EF2162 ORF corresponds to the miaA gene, which encodes a 309 amino acid protein sharing high similarity with tRNA $\Delta^{2}$ isopentenylpyrophosphate transferase (tRNA and rRNA base modification). Four base pairs downstream of the miaA gene, the EF2161 ORF encodes a 413 amino-acid putative GTP-binding protein. This latter is followed by an inverted repeat (5'-TAGAAATGATTTGT $\left(\mathrm{N}_{4}\right)$ ACAAATCATTTCTA-3'; $\left.\Delta G=-16.4 \mathrm{kcal} \mathrm{mol}^{-1} ;-68.6 \mathrm{~kJ} \mathrm{~mol}^{-1}\right)$, which could act as a rho-independent terminator. Further experiments were performed only with mutants 35A1 (pde inactivated), $36 \mathrm{H} 4$ ( $g l p \mathrm{Q}$ inactivated) and $35 \mathrm{H} 1$ (rpoN inactivated).

\section{mRNA transcriptional analysis and complementation test}

To identify accurately genes associated with resistance of Ent. faecalis JH2-2 to DvnV41, RT-PCR analyses were performed in order to study the mode of transcription of the inactivated genes as well as those located downstream of them. Thus, in mutant $36 \mathrm{H} 4$, defective in the putative GlpQ protein, the $g l p Q$ gene (EF2163 ORF) was shown to be cotranscribed with the miaA gene (EF2162 ORF), and the gene encoding a putative GTP-binding protein (EF2161 ORF) was itself cotranscribed with the $g \ln R$ gene (EF2160 ORF) (Figs 1a and 2a). Regarding these RT-PCR results, we cannot discard a polar mutational effect resulting from the inactivation of the target $g l p Q$ gene. This inactivation could lead to either down- or up-regulation of miaA (EF2162 ORF), the gene encoding a putative GTP-binding protein (EF2161 ORF), and even $g \ln R$ (EF2160 ORF) located downstream of the putative rho-independent terminator, as a band corresponding to a read-through transcript was obtained with primers J2161F and J2160R (Fig. 1). The same is true for the gene encoding a putative phosphoesterase (EF0011 ORF), which was found to be cotranscribed with the rpII gene (EF0012 ORF), which was itself cotranscribed with the $d n a B$ gene (EF0013 ORF) (Figs 1b and $2 \mathrm{~b}$ ). However, as no RT-PCR product was detected with primers J0782F and J0783R (Fig. 2c), the $r p o N$ gene (EF0782 ORF) appeared to be expressed as a monocistronic mRNA. To clearly ascribe resistance of Ent. faecalis $35 \mathrm{~A} 1$ and $36 \mathrm{H} 4$ 
(a) Mutant 36H4

(b) Mutant 35A1
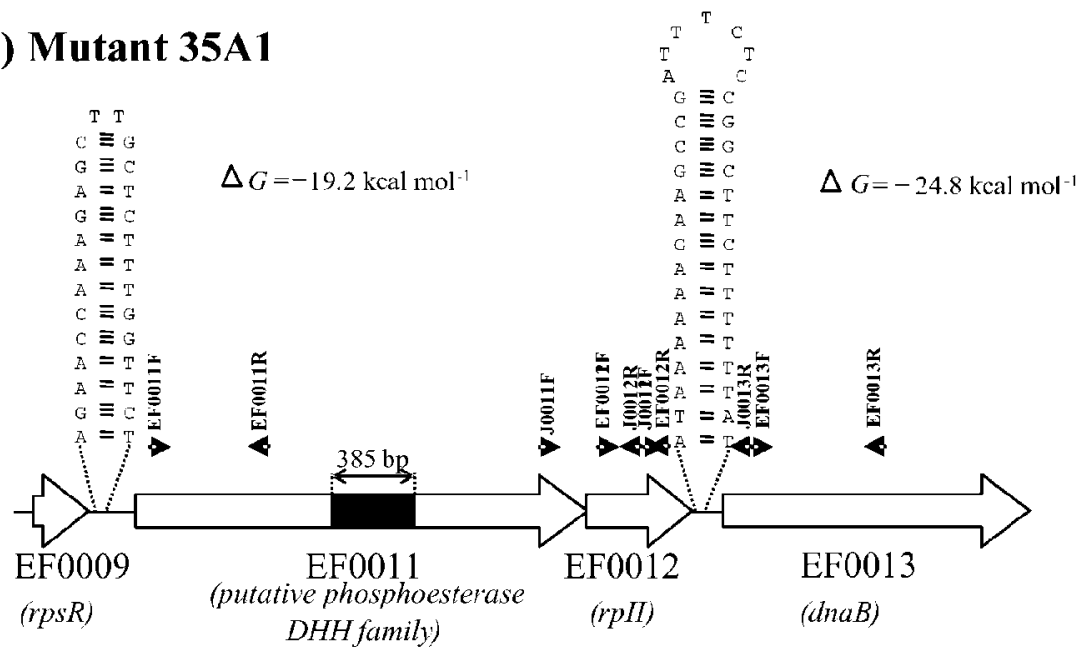

(c) Mutant 35H1

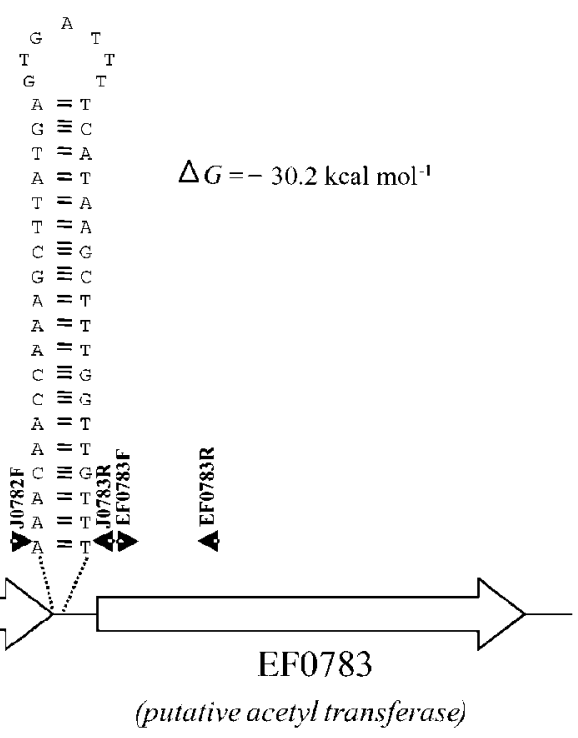

Fig. 1. Genetic organization of the Ent. faecalis chromosomal region surrounding integration loci in DvnV41-resistant mutants. Large arrows represent the ORFs and their orientation shows the transcriptional direction; black boxes represent the DNA regions harbouring plasmids integrated into the genomes of mutants; the black triangle represents a tRNA gene. The nucleotide sequences of the putative rho-independent terminators are shown. Primers used in RT-PCR experiments are indicated by black arrows. 


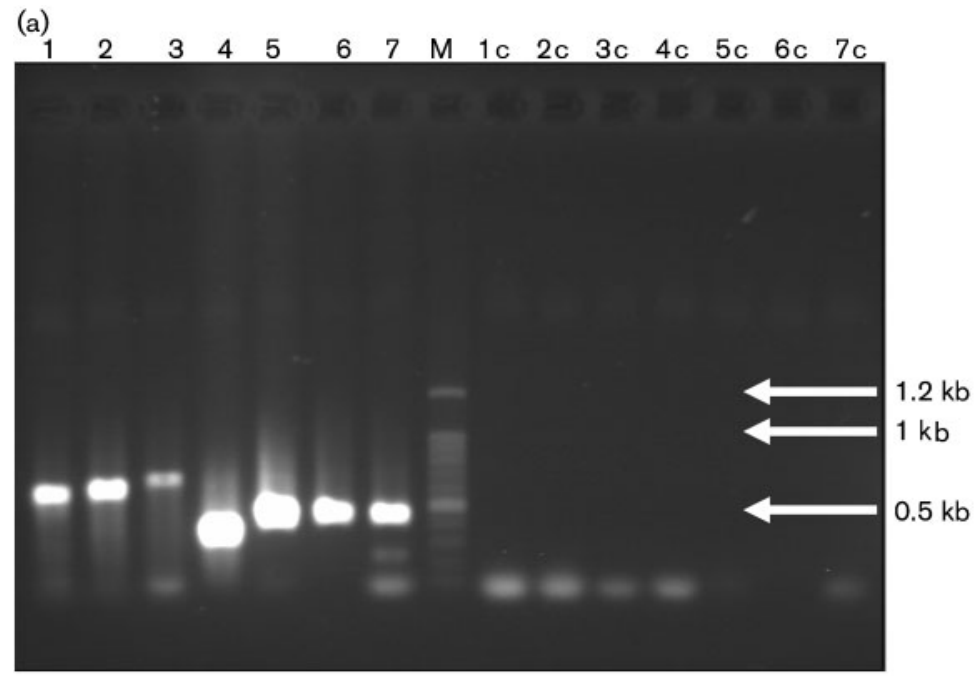

(b)

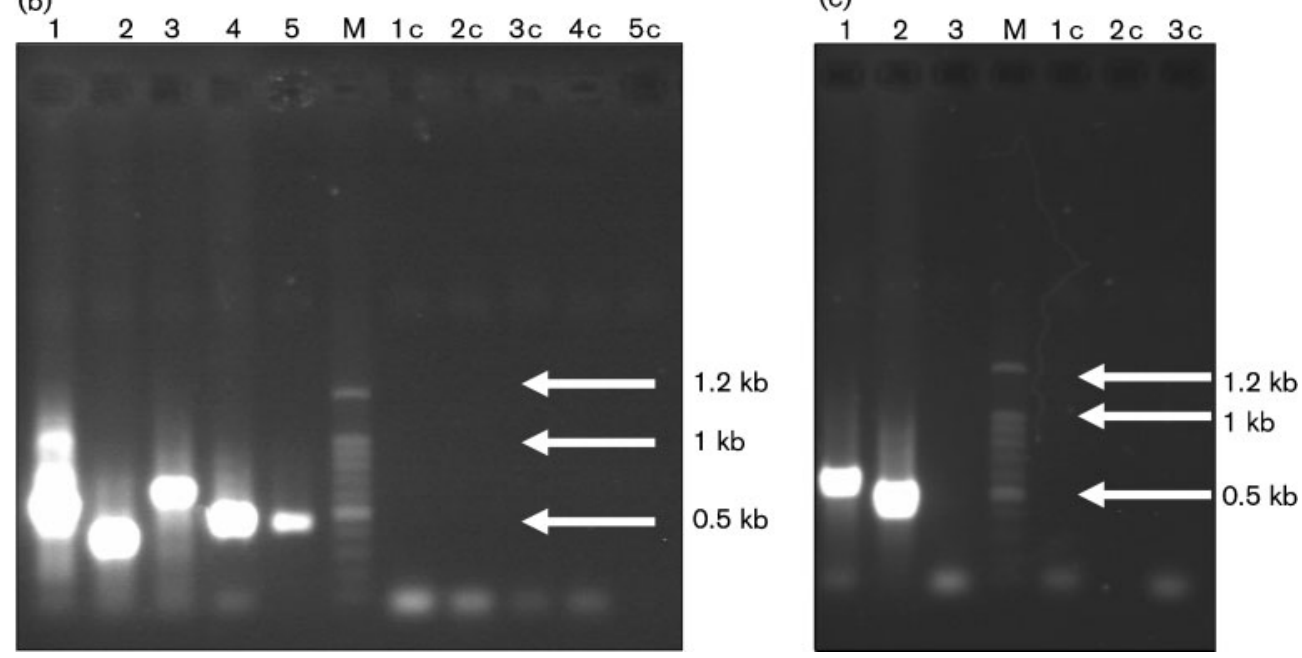

Fig. 2. RT-PCR assays conducted on mRNAs isolated from exponentially growing Ent. faecalis JH2-2 cells in GM17 broth. Reverse transcription was performed with random hexamer primers. In (a) PCR was performed with primers EF2163F and EF2163R (lanes 1 and 1c), EF2162F and EF2162R (lanes 2 and 2c), EF2161F and EF2161R (lanes 3 and 3c), EF2160F and EF2160R (lanes 4 and 4c), J2163F and J2162R (lanes 5 and 5c), J2162F and J2161R (lanes 6 and 6c) and J2161F and J2160R (lanes 7 and 7c). To ensure the absence of genomic DNA, negative controls were performed without reverse transcriptase (lanes 1c-7c). In (b) PCR was performed with primers EF0011F and EF0011R (lanes 1 and 1c), EF0012F and EF0012R (lanes 2 and 2C), EF0013F and EF0013R (lanes 3 and 3c), J0011F and J0012R (lanes 4 and 4c) and J0012F and J0013R (lanes 5 and 5c). Lanes 1c-5c correspond to the negative controls. In (c) PCR was performed with primers EF0783F and EF0783R (lanes 1 and 1C), EF0782F and EF0782R (lanes 2 and 2c) and J0782F and J0783R (lanes 3 and 3c). Lanes $1 \mathrm{c}-3 \mathrm{c}$ contain the negative controls. Lane M contains DNA fragments of the ' $100 \mathrm{bp}$ DNA ladder' (Promega) molecular mass marker.

to inactivation of $p d e$ and $g l p Q$ genes rather than a polar effect of genes located in the neighbourhood, we performed a complementation test by incorporation in trans in each mutant pAM401 plasmids containing either the pde or $g l p Q$ gene. The new strains (transformants) $35 \mathrm{~A} 1+$ pde and $36 \mathrm{H} 4+g l p Q$ exhibited similar phenotypes to wild-type Ent. faecalis JH2-2 (Fig. 3a), whilst transformants harbouring only pAM401 vector remained resistant to DvnV41 (data not shown).

\section{Characterization of Ent. faecalis JH2-2 mutants resistant to DvnV41}

To examine if the DvnV41-resistant phenotype could be attributed to plasmid insertion, and not to an independent genomic mutation, the Ent. faecalis $\mathrm{JH} 2-2$ mutants $35 \mathrm{~A} 1$, $36 \mathrm{H} 4$ and $35 \mathrm{H} 1$ were cured of their pORI19 recombinant plasmid as described previously (Connil et al., 2002). This resulted in the restoration of the DvnV41-sensitive 
(a)
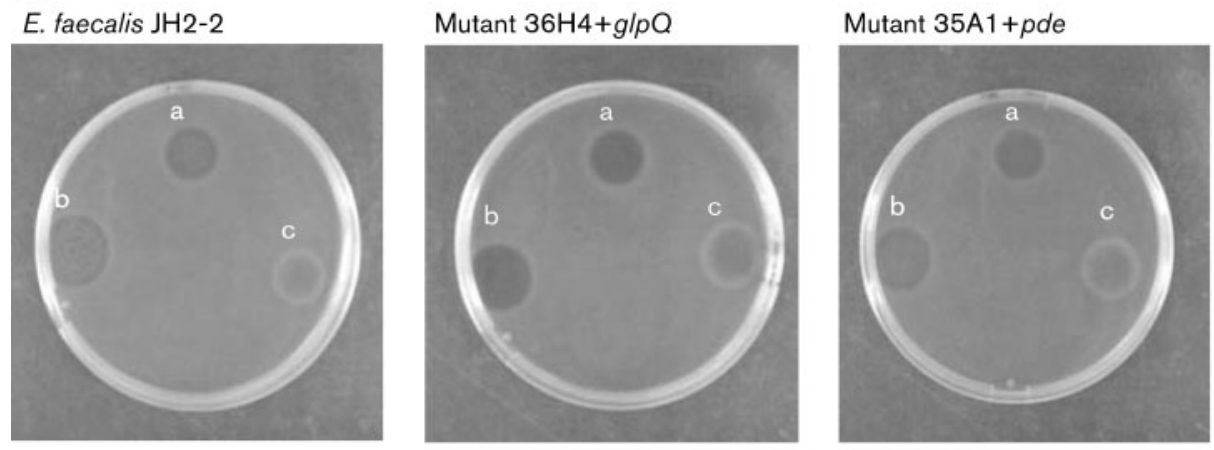

(b)

E. faecalis $\mathrm{JH} 2-2$

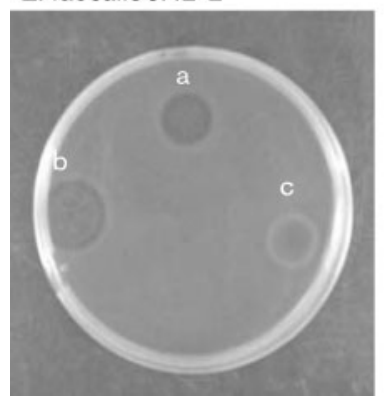

Mutant $36 \mathrm{H} 4$

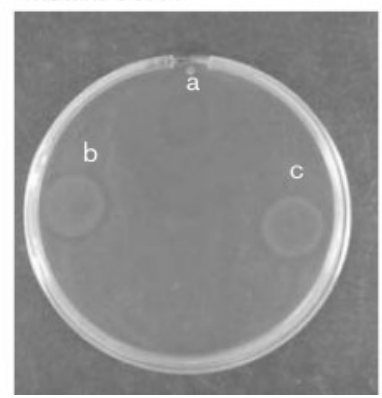

Mutant 35A1

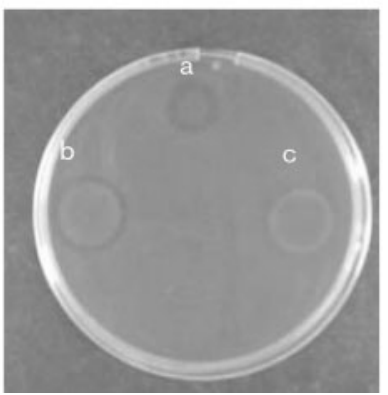

Mutant $35 \mathrm{H} 1$

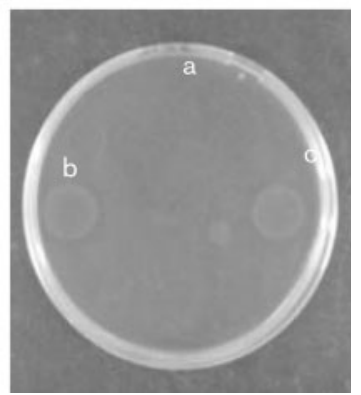

Fig. 3. Agar diffusion test (ADT) showing (a) complementation of mutants $36 \mathrm{H} 4+g / p Q$ and $35 \mathrm{~A} 1+p d e$ and (b) resistance of Ent. faecalis JH2-2 and mutants $35 \mathrm{H} 1,36 \mathrm{H} 4,35 \mathrm{~A} 1$ to (a) DvnV41, (b) PedA-1/AcH (c) MesY105.

phenotype, proving that plasmid insertion was responsible for this resistant phenotype (data not shown). Further experiments, based on phenotypic and molecular tests, were performed to confirm the enterococcal identity of each strain. As a result, all the strains were shown to be Grampositive bacteria, cocci associated in pairs, and devoid of both catalase and oxidase activities. The identification procedure was completed by PCR-RAPD using the oligonucleotide primer M13V (Muller et al., 2001). The PCR-RAPD profiles of the wild-type and mutant strains were identical (data not shown).

Growth characteristics of Ent. faecalis JH2-2 and its mutant derivatives were determined and compared. In the absence of DvnV41, the growth rates of wild-type and mutant strains were not significantly different. Addition of $5 \mu \mathrm{l}$ of DvnV41, at $820000 \mathrm{AU} \mathrm{ml}^{-1}$, to $150 \mu \mathrm{l}$ cultures, did not affect the growth rate of the mutant strains but extended the lag period of the wild-type strain by $4 \mathrm{~h}$, or even $8 \mathrm{~h}$ when the amount of DvnV41 was doubled (data not shown). Characterization of the sensitivity of wild-type and mutant strains was carried out by measuring the MIC of DvnRV41, which ranged between 0.22 and $112 \mu \mathrm{g} \mathrm{ml}^{-1}$ (Table 2). The lowest value was obtained for the wild-type strain, which was 100 times more sensitive than mutants 35A1 (defective phenotype in putative PDE) and $36 \mathrm{H} 4$ (defective phenotype in putative GlpQ) and 500 times more sensitive than mutant $35 \mathrm{H} 1$ (defective phenotype in $\sigma^{54}$ factor RNA polymerase).

\section{Cross-resistance}

Table 3 summarizes the related cross-resistance obtained with class IIa bacteriocins (DvnV41, Ped PA-1/AcH and MesY105), class I bacteriocin (nisin), and antibiotics. In direct comparison, the cross-resistance exhibited by the mutant strains to class IIa bacteriocins (Table 3; Fig. 3b) is in agreement with that formerly reported (Dalet et al., 2000; Ramnath et al., 2000; Gravesen et al., 2002). Notably, the resistance was evaluated by two independent experiments including ADT and MIC (Tables 2 and 3). Both tests indicated that the resistance to DvnV41 developed by the wild-type and mutant strains was graduated since mutant $35 \mathrm{H} 1$ (defective in $\sigma^{54}$ factor) was more resistant than mutant $36 \mathrm{H} 4$ (defective in putative GlpQ), which was itself slightly more resistant than the mutant 35A1 (defective in putative PDE) (Table 3 ). In contrast, no difference was revealed between the wild-type and mutant strains in terms of resistance to nisin (Table 3 ). The partial crossresistance to class IIa bacteriocins, but not to the class I bacteriocin nisin, is consistent with the results of Dalet et al. (2000). Concerning resistance to antibiotics, there was no difference between the phenotype of Ent. faecalis JH2-2 wild-type and the three mutants. In summary, we suggest 
Table 2. MIC for Ent. faecalis $\mathrm{JH} 2-2$ wild-type and DvnV41-resistant mutant strains towards DvnRV41

Values are means of triplicate independent experiments.

\begin{tabular}{|lclc|}
\hline Strain & Gene knock-out & \multicolumn{1}{c|}{ Putative function } & $\begin{array}{c}\text { MIC } \\
\left(\boldsymbol{\mu} \mathbf{m o l ~ m l}^{-\mathbf{1}}\right)\end{array}$ \\
\hline Ent. faecalis JH2-2 wild-type & - & & - \\
Mutant 35A1 $(p d e)$ & EF0011 & Phosphoesterase & 0.22 \\
Mutant 36H4 $(g l p Q)$ & EF2163 & Glycerophosphodiester phosphodiesterase & 28 \\
Mutant 35H1 $(r p o N)$ & EF0782 & $\sigma^{54}$ factor RNA polymerase & 112 \\
\hline
\end{tabular}

that a cross-resistance exists to class IIa bacteriocins but not to nisin and antibiotics.

\section{DISCUSSION}

\section{Resistance to class Ila bacteriocins}

High-level resistance of Ent. faecalis, L. monocytogenes and some other Gram-positive bacteria to class IIa bacteriocins results from the loss of $m p t$ expression, either in defined mutants or in spontaneous resistant strains (Gravesen et al., 2002). The mpt operon encodes a mannose permease $\left(\mathrm{EII}_{\mathrm{t}}^{\mathrm{Man}}\right)$ which belongs to the (PTS. The level of $m p t$ expression correlates with the level of sensitivity (Dalet et al., 2001; Héchard et al., 2001), which implies that $\mathrm{EII}_{\mathrm{t}}^{\mathrm{Man}}$ permease might be a target molecule for class IIa bacteriocins. Given that the IIC and IID subunits are probably present in the membrane, they are potential targets of class IIa bacteriocins. The mptACD operon of $L$. monocytogenes heterologously expressed in an insensitive species, such as Lactococcus lactis (Ramnath et al., 2004), renders this strain sensitive to various class IIa bacteriocins. Each gene of the mptACD operon was expressed independently in Lac. lactis and the expression of $m p t C$ alone was found to be sufficient to confer sensitivity. The IIC subunit has therefore been proposed as the target molecule of the class IIa bacteriocins (Ramnath et al., 2004). Spontaneous resistance of $L$. monocytogenes is accompanied by a respective increase and decrease of two phosphoenolpyruvate-dependent PTSs, which are responsible for sugar uptake and phosphorylation in Gram-negative and Grampositive bacteria (Postma et al., 1993).

\section{How is resistance to DvnV41 mediated in L. monocytogenes and Ent. faecalis JH2-2?}

Earlier attempts to unravel the resistance of L. monocytogenes to DvnV41 involved a proteomic approach, comparing protein profiles of $L$. monocytogenes wild-type and a mutant resistant to DvnV41. L. monocytogenes with a DvnV41-resistant phenotype displayed differential protein synthesis (Duffes et al., 2000). This mutant strain lacked at least nine protein spots, two of which have, interestingly, a molecular mass and $\mathrm{pI}$ matching those of the $m p t A$ cluster, which is controlled by the $\sigma^{54}$ transcription factor in coordination with the ManR regulator (Dalet et al., 2001). Undoubtedly, the identification of the proteins present within the two spots will be of major interest in understanding the resistance of L. monocytogenes to DvnV41. In the present study, we have identified three genes associated with the resistance of Ent. faecalis $\mathrm{JH} 2-2$ to DvnV41. The first one is the $\operatorname{rpoN}$ gene, which encodes the $\sigma^{54}$ factor, an alternative subunit of RNA polymerase responsible for the transcription of a specific set of genes. The $r p o N$ gene may or may not be involved directly in a general mechanism of sensitivity to class IIa bacteriocins. It has been postulated

Table 3. Resistance of Ent. faecalis JH2-2 wild-type and DvnV41-mutant strains to antibiotics and bacteriocins

\begin{tabular}{|c|c|c|c|c|c|c|c|}
\hline \multirow[t]{2}{*}{ Strain } & \multicolumn{7}{|c|}{ Diameter $(\mathrm{mm})$ of inhibition zone for antibiotic or bacteriocin ${ }^{\star}$} \\
\hline & $\begin{array}{c}\text { Penicillin } \\
\text { G } \dagger\end{array}$ & Streptomycin $\dagger$ & Cephalosporin $\ddagger$ & Nisin $\ddagger$ & $\begin{array}{c}\text { Divercin } \\
\text { V41 } \neq(\text { DvnV41) }\end{array}$ & $\begin{array}{c}\text { Pediocin } \\
\text { PA-1/AcH } \ddagger\end{array}$ & $\begin{array}{c}\text { Mesentericin } \\
\text { Y105 } \ddagger\end{array}$ \\
\hline Ent. faecalis JH2-2 wild-type & 23 & 10 & 25 & 11 & 15 & 14 & 11 \\
\hline Mutant 35A1 (pde) & 24 & 10 & 25 & 11 & $15 \S$ & $14 \$$ & $11 \S$ \\
\hline Mutant $36 \mathrm{H} 4(\mathrm{glpQ})$ & 24 & 9 & 25 & 11 & $15 \|$ & $14 \|$ & 0 \\
\hline
\end{tabular}

*Values are the means of three experiments.

$\dagger$ Determined by disk diffusion method.

‡Determined by agar diffusion test.

$\S$ Limits of inhibition halo can be measured but halo is blurred.

॥Halo is more blurred than $\S$. 
that $r p o N$ is involved in the expression of a target molecule for class IIa bacteriocins, loss of whose expression leads to resistance (Drider et al., 2006). The second gene identified encodes a putative glycerophosphoryl diester phosphoesterase (GlpQ). GlpQ is an exoprotein found to participate in fatty acid and phospholipid degradation in many bacteria (Antelmann et al., 2000). A hypothesis that could be drawn from our data is that the absence of GlpQ activity in mutant $36 \mathrm{H} 4$ leads to an intact fatty acid and phospholipid composition of the cell membrane, which should contribute to the resistant phenotype of this mutant. Moreover, the GlpQ protein was originally suggested to belong to the Pho regulon in Bacillus subtilis (Antelmann et al., 2000), and to be governed by a pleiotropic two-component regulatory system PhoP-PhoR (Groisman, 2001). Interestingly, PhoP and $\mathrm{Mg}^{2+}$ also control the resistance of many Gramnegative bacteria to antimicrobial peptides, as supported by a number of lines of evidence (Groisman et al., 1992; Moss et al., 2001). Similarly, in Gram-positive bacteria, different studies have highlighted the role of a two-component regulatory system in the resistance of $L$. monocytogenes (Cotter et al., 2002), Ent. faecalis (Comenge et al., 2003) and Staphylococcus aureus (Kuroda et al., 2003) to inhibiting substances such as antimicrobial peptides and antibiotics. At present, it is unclear what contribution a two-component regulatory system makes to Ent. faecalis JH2-2 under harsh environmental conditions with a significant amount of DvnV41. To answer this question, and in order to gain a more comprehensive view of the role of a two-component signal transduction system pathway in resistance to pediocin-like bacteriocins, we examined the resistance of each insertional mutant characterized so far in Ent. faecalis JH2-2 (Le Breton et al., 2003) and Ent. faecalis V583 (Hancock \& Perego, 2004). The results obtained reject any relationship between a two-component regulatory system and resistance to DvnV41. Finally, the third gene identified encodes a putative phosphoesterase (PDE), which belongs to the DHH family. At this stage of investigation, it is quite difficult to unravel the role of phosphoesterase in resistance mechanism of Ent. faecalis JH2-2 to divercin V41. The resistance measured by the ADT (Table 3 ) showed that the size of the inhibition halo is pediocin-like bacteriocin dependent. Interestingly, the resistance of mutant $36 \mathrm{H} 4$ to MesY105 was higher than that observed to DvnV41; this could be explained by the activity and/or potency of each bacteriocin.

Overall, it is clear that the $r p o N$ gene is associated with the high level resistance and the newly identified genes with the intermediate resistance of Ent. faecalis JH2-2 to DvnV41, MesY105 and Ped PA-1/Ach.

\section{ACKNOWLEDGEMENTS}

The authors would like to thank Manolo Espinosa and Gisèle LaPointe for critical reading of the manuscript, Carol Robins for improvement of the English, Marta Perego and Pascale Serror for providing us with Ent. faecalis V583 mutant strains, and Kurt W. Miller for kindly providing the pAM401 vector. Ségolène Calvez received a $\mathrm{PhD}$ grant awarded by 'La Région des Pays de la Loire'. This work was partly supported by 'La Région des Pays de la Loire' and the European Union through VANAM II and the 6th PCRD, SEAFOODplus project, respectively.

\section{REFERENCES}

Antelmann, H., Scharf, C. \& Hecker, M. (2000). Phosphate starvation-inducible proteins of Bacillus subtilis: proteomics and transcriptional analysis. J Bacteriol 182, 4478-4490.

Bouttefroy, A. \& Millière, J. B. (2000). Nisin-curvacitin 13 combinations for avoiding regrowth of bacteriocin resistant cells of Listeria monocytogenes ATCC 15313. Int J Food Microbiol 62, 65-75.

Cleveland, J., Montville, T. J., Nes, I. F. \& Chikindas, M. L. (2001). Bacteriocins: safe natural antimicrobials for food preservation. Int J Food Microbiol 71, 1-20.

Comenge, Y. R., Quintiliani, R., Jr, Li, L., Dubost, L., Brouard, J. P., Hugonnet, J. E. \& Arthur, M. (2003). The CroRS two component regulatory system is required for intrinsic beta-lactam resistance in Enterococcus faecalis. J Bacteriol 185, 7184-7192.

Connil, N., Le Breton, Y., Dousset, X., Auffray, Y., Rincé, A. \& Prévost, H. (2002). Identification of the Enterococcus faecalis tyrosine decarboxylase operon involved in tyramine production. Appl Environ Microbiol 68, 3537-3544.

Cotter, P. D., Guinane, C. M. \& Hill, C. (2002). The LisRK signal transduction system determines the sensitivity of Listeria monocytogenes to nisin and cephalosporins. Antimicrob Agents Chemother 46, 2784-2790.

Dalet, K., Briand, C., Cenatiempo, Y. \& Héchard, Y. (2000). The rpoN gene of Enterococcus faecalis directs sensitivity to subclass IIa bacteriocins. Curr Microbiol 41, 441-443.

Dalet, K., Cenatiempo, Y., Cossart, P. \& Héchard, Y. (2001). A $\sigma^{54}$ dependent PTS permease of the mannose family is responsible for sensitivity of Listeria monocytogenes to mesentericin Y105. Microbiology 147, 3263-3269.

Drider, D., Fimland, G., Héchard, Y., McMullen, L. M. \& Prévost, H. (2006). The continuing story of class IIa bacteriocins. Microbiol Mol Biol Rev 70, 564-582.

Duffes, F., Jenoe, P. \& Boyaval, P. (2000). Use of two dimensional electrophoresis to study differential protein expression in divercin V41-resistant and wild type strains of Listeria monocytogenes. Appl Environ Microbiol 66, 4318-4326.

Dykes, G. A. \& Hastings, J. W. (1998). Fitness costs associated with class IIa bacteriocin resistance in Listeria monocytogenes B73. Lett Appl Microbiol 26, 5-8.

Ennahar, S., Sashihara, T., Sonomoto, K. \& Ishizaki, A. (2000). Class IIa bacteriocins: biosynthesis, structure and activity. FEMS Microbiol Rev 24, 85-106.

Frégeau-Gallagher, N. L., Sailer, M., Niemczura, W. P., Nakashima, T. T., Stiles, M. E. \& Vederas, J. C. (1997). Three-dimensional structure of leucocin A in trifluoroethanol and dodecylphosphocholine micelles: spatial location of residues critical for biological activity in type IIa bacteriocins from lactic acid bacteria. Biochemistry 36, 15062-15072.

Gravesen, A., Ramnath, M., Rechinger, K. B., Andersen, N., Jansch, L., Héchard, Y., Hastings, J. W. \& Knochel, S. (2002). High-level resistance to class IIa bacteriocins is associated with one general mechanism in Listeria monocytogenes. Microbiology 148, 2361-2369.

Groisman, E. A. (2001). The pleiotropic two-component regulatory system PhoP-PhoQ. J Bacteriol 183, 1835-1842. 
Groisman, E. A., Heffron, F. \& Solomon, F. (1992). Molecular genetic analysis of the Escherichia coli phoP locus. J Bacteriol 174, 486-491.

Hancock, L. E. \& Perego, M. (2004). Systematic inactivation and phenotypic characterization of two-component signal transduction systems of Enterococcus faecalis V583. J Bacteriol 186, 7951-7958.

Héchard, Y., Derijard, B., Lettelier, F. \& Cenatiempo, Y. (1992). Characterization and purification of mesentericin Y105, an antiListeria bacteriocin from Leuconostoc mesenteroides. J Gen Microbiol 138, 2725-2731.

Héchard, Y., Pelletier, C., Cenatiempo, Y. \& Frère, J. (2001). Analysis of $\sigma^{54}$-dependent genes in Enterococcus faecalis: a mannose PTS permease (EIIMan) is involved in sensitivity to a bacteriocin, mesentericin Y105. Microbiology 147, 1575-1580.

Hofmann, K. \& Stoffel, W. (1993). TMbase - a database of membrane spanning proteins segments. Biol Chem Hoppe-Seyler 374, 166.

Kuroda, M., Kuroda, H., Oshima, T., Takeuchi, F., Mori, H. \& Hiramatsu, K. (2003). Two-component system VraSR positively modulates the regulation of cell-wall biosynthesis pathway in Staphylococcus aureus. Mol Microbiol 49, 807-821.

Law, J., Buist, G., Haandrikman, A., Kok, J., Venema, G. \& Leenhouts, K. (1995). A system to generate chromosomal mutations in Lactococcus lactis which allows fast analysis of targeted genes. J Bacteriol 177, 7011-7018.

Le Breton, Y., Mazé, A., Hartke, A., Lemarinier, S., Auffray, Y. \& Rincé, A. (2002). Isolation and characterization of bile salts-sensitive mutants of Enterococcus faecalis. Curr Microbiol 45, 434-439.

Le Breton, Y., Boël, G., Benachour, A., Prévost, H., Auffray, Y. \& Rincé, A. (2003). Molecular characterization of Enterococcus faecalis two-component signal transduction pathways related to environmental stresses. Environ Microbiol 5, 329-337.

Maguin, E., Duwat, T., Hege, T., Ehrlich, D. \& Gruss, A. (1992). New thermosensitive plasmid for gram-positive bacteria. J Bacteriol 174, 5633-5638.

Moss, J. E., Fisher, P. E., Vick, B., Groisman, E. A. \& Zychilinsky, A. (2001). The regulatory protein PhoP controls the resolution of Shigella flexneri infections. Cell Microbiol 2, 443-452.

Muller, M. R. A., Wolfrum, G., Stolz, P., Ehrmann, M. A. \& Vogel, R. F. (2001). Monitoring the growth of Lactobacillus species during a rye flour fermentation. Food Microbiol 18, 217-227.

Naghmouchi, K., Drider, D., Kheadr, E., Lacroix, C., Prévost, H. \& Fliss, I. (2006). Multiple characterizations of Listeria monocytogenes sensitive and insensitive variants to divergicin M35, a new pediocinlike bacteriocin. J Appl Microbiol 100, 29-39.

Pilet, M. F., Dousset, X., Barré, R., Novel, G., Desmazaud, M. \& Piard, J. C. (1995). Evidence for two bacteriocins produced by Carnobacterium piscicola and Carnobacterium divergens isolated from fish and active against Listeria monocytogenes. J Food Prot 58, 256-262.

Postma, P. W., Lengeler, J. W. \& Jacobson, G. R. (1993). Phosphoenolpyruvate: carbohydrate phosphotransferase systems of bacteria. Microbiol Rev 57, 543-594.
Ramnath, M., Beukes, M., Tamura, K. \& Hastings, J. W. (2000). Absence of a putative mannose-specific phosphotransferase system enzyme IIAB component in a leucocin A-resistant strain of Listeria monocytogenes, as shown by two-dimensional sodium dodecyl sulfate-polyacrylamide gel electrophoresis. Appl Environ Microbiol 66, 3098-3101.

Ramnath, M., Arous, S., Gravensen, A., Hastings, J. W. \& Héchard, Y. (2004). Expression of $m p t C$ of Listeria monocytogenes induces sensitivity to class IIa bacteriocins in Lactococcus lactis. Microbiology 150, 2663-2668.

Rekhif, N., Atrih, A. \& Lefèbvre, G. (1994). Selection and properties of spontaneous mutants of Listeria monocytogenes ATCC 15313 resistant to different bacteriocins produced by lactic acid bacteria strains. Curr Microbiol 28, 237-241.

Richard, C., Drider, D., Elmorjani, K., Marion, D. \& Prévost, H. (2004). Heterologous expression and purification of active divercin V41, a class IIa bacteriocin encoded by a synthetic gene in Escherichia coli. J Bacteriol 186, 4276-4284.

Terzaghi, B. E. \& Sandine, W. E. (1975). Improved medium for lactic streptococci and their bacteriophages. Appl Environ Microbiol 29, 807-813.

Uhart, M., Ravishankar, S. \& Maks, N. D. (2004). Control of Listeria monocytogenes with combined antimicrobials on beef franks stored at $4{ }^{\circ}$ C. J Food Prot 67, 2296-2301.

Uteng, M., Hauge, H. H., Markwick, P. R., Fimland, G., Mantzilas, D., Nissen-Meyer, J. \& Muhle-Goll, C. (2003). Three-dimensional structure in lipid micelles of the pediocin-like antimicrobial peptide sakacin $\mathrm{P}$ and a sakacin $\mathrm{P}$ variant that is structurally stabilized by an inserted C-terminal disulfide bridge. Biochemistry 42, 11417-11426.

Vadyvaloo, V., Hastings, J. W., van der Merwe, M. J. \& Rautenbach, M. (2002). Membranes of class IIa bacteriocin-resistant Listeria monocytogenes cells contain increased levels of desaturated and short-acylchain phosphatidylglycerols. Appl Environ Microbiol 8, 5223-5230.

Vadyvaloo, V., Snoep, J. L., Hastings, J. W. \& Rautenbach, M. (2004). Physiological implications of class IIa bacteriocins resistance in Listeria monocytogenes. Microbiology 150, 335-340.

Wachsman, M. B., Farias, M. E., Takeda, E., Sesma, F., de Ruiz Holgado, A. P., de Torres, R. A. \& Coto, C. E. (1999). Antiviral activity of enterocin CRL35 against herpes viruses. Int J Antimicrob Agents 12, 293-299.

Wachsman, M. B., Castilla, V., de Ruiz Holgado, A. P., de Torres, R. A., Sesma, F. \& Coto, C. E. (2003). Enterocin CRL35 inhibits late stages of HSV-1 and HSV-2 replication in vitro. Antiviral Res 58, $17-24$.

Wirth, R., An, F. Y. \& Clewell, D. B. (1986). Highly efficient protoplast transformation system for Streptococcus faecalis and a new Escherichia coli-S. faecalis shuttle vector. J Bacteriol 165, 831-836.

Yagi, Y. \& Clewell, D. B. (1980). Recombination-deficient mutant of Streptococcus faecalis. J Bacteriol 143, 966-970.

Edited by: G. M. Dunny 